\title{
The Developing Country Reactions to Biomedical Techniques and Plant Biotechnology: The Tunisian Experience
}

\author{
Fethi Tebourski* and Amel Ben Ammar-Elgaaied \\ Laboratoire de Génétique, Immunologie et Biotechnologie, Département des Sciences Biologiques, \\ Faculté des Sciences de Tunis, Campus Universitaire, \\ Le Belvédère 1060 Tunis, Tunisia
}

Received 16 January 2004; accepted 18 March 2004

\begin{abstract}
In the present study we present the conditions offered to biotechnology development in Tunisia and we compare three main biotechnology applications which raise ethical and health problems: organ transplant, assisted reproductive techniques, and genetically modified organisms. We try to identify factors that have allowed success of the first two applications and failure of the latter. Conditions offered to biotechnology in other African countries are also discussed.
\end{abstract}

\section{INTRODUCTION}

For biotechnology development, some conditions are required but are not always provided at the adequate level in each country. These conditions include:

(1) the role of different actors such as scientists, educators, journalists, politicians, and economic partners;

(2) the existence of specialized structures concerned with biotechnology (research, training, coordination, and supervision structures);

(3) the functioning of democratic mechanisms which enable civil society to act its will (ethics committees, laws regulating biotechnology, monitoring structures, and technological means).

Our purpose is to evaluate to which extent these conditions are offered to biotechnology development in Tunisia and to compare the attitudes towards and the conditions offered to biotechnology development in Tunisia through three examples: organ transplant (OT), assisted reproductive techniques (ART), and genetically modified organisms (GMOs), in order to identify the factors that have allowed success of the first two applications and failure of the latter. In practice, the OT, ART, and GMOs are the main biotechnology applications which raised public interest which concerns ethical problems in Tunisia.

\section{THE EXAMPLES OF THREE BIOTECHNOLOGY APPLICATIONS IN TUNISIA}

\section{Organ transplant}

Conditions offered for OT development concern information, specialized structures, and legislation. Good level of information is provided by radio and TV programs and by papers in the local press on organ donation. A National Day of Organ Donation Awareness has been instituted. Technological structures consist in a National Center for Bone Marrow transplant, a bank for tissues and eyes, the Blood Transfusion National Center, and immunology laboratories (HLA typing). The last creation in June 1995 is the National Center for Organs Transplantation Promotion (NCOTP). The aims of this centre are increasing awareness for organ donation, establishing a waiting list of patients for OT, ensuring transparency and safety of OT, training of medical and paramedical staff, training and coordination between medical teams. With regard to legislation, two laws are particularly in favour of OT: the law 91-22 created in March 1991 and regulating OT [1] and the law on the "donor mention" registered on the National Identity Card of the donor [2]. The spirit of these laws was to promote organ donation (Table 1).

For OT issues, the High Islamic Council (HIC) has published its academic resolution authorizing OT [3, 4]. Tunisia was the first African country to set up a National Medical Ethics Committee (NMEC). Tunisia's NMEC is rather in favour of OT [5]. Statistics of the year 
TABLE 1. The main points of the two laws on organ transplantation (OT) in Tunisia.

(1) The law 91-22 created in March 1991 and regulating organ transplant

Art.3. It is allowed to remove an organ from a human corpse for therapeutic or scientific purposes unless there is objection from the dead person while alive or after death from the entitled individuals as mentioned in the following order: the children, the father, the mother, the partner, the brothers and sisters and tutor.

Art.8. Donor should show consent for organ donation before the court. A copy of his consent will be delivered to all the authorized hospitals to practice organs transplant.

Art.9. Donor's consent could be withdrawn by the donor before the operation without formality.

Art.15. No removal for therapeutic purposes could be done without the statement of death (by two physicians other than those who will realize removal and organs transplant).

(2) The law 99-18 created in March 1999 relative to the "donor mention" registered on National Identity Card of the donor The National Identity Card could carry a mention "Donor" which confirms the agreement to make human organ donation after death. This agreement could be removed through a registered document of the giving up.

TABle 2. Some recommendations of the Tunisia's National Medical Ethics Committee with regard to the assisted reproductive techniques (ART).

(1) Absolute necessity to respect the religious, philosophical and ethical principles of the Tunisian society (the respect of life and the respect of filiation).

(2) ART must be allowed only for legitimate couples and not to single women.

(3) The couple must be consent and informed of the risk to take (eg, ovarian stimulation, extra-uterine pregnancy).

(4) The preserved embryo should not be kept beyond the fertility period of the couple or the death of one partner.

(5) Necessity to establish clear criteria concerning the conditions of practice of ART (competent clinicians and biologists, medical control and transparency in the statistics).

TABLE 3. The main points of the law relative to the assisted reproductive techniques (ART) in Tunisia.

The law 01-93 created in August 2001 and regulating ART

Art.4. There is no way to ART except only for a married and alive couple through gametes that should necessarily be coming from them and for the couple to be at a reproducing age.

Art.9. It is forbidden to get embryos through the fecundation in vitro or other techniques for study, research or experimentation.

Art.11. Gametes or embryos could be preserved only for therapeutic purposes to help the couple to procreate and after a written demand from the couple.

Art.14. Gametes or embryos donation is forbidden in the ART.

Art.15. It is forbidden to use the womb (womb-leasing) of another women to allow the embryo development.

2000, in authorized public hospitals, permit to record the realization of 43 transplantations (kidney: 39; heart: 1; and liver: 3 ) and 626 grafts (cornea: 578 and marrow: 50) (Activity report of National Center for Organs Transplantation Promotion, Tunisia, 2001).

\section{Assisted Reproductive Techniques}

The second technology which is much in demand is the ART. A percentage of $10 \%-15 \%$ of Tunisian couples are concerned, with 6000 to 8000 candidates for ART per year. With regard to the success rate, it was about 7\%$20 \%$. The available methods proposed to couples suffering from infertility are artificial insemination, in vitro fertilization, and the microinjection technique. The in vitro fertilization (IVF) is available since 1991 in private and in public hospitals and many hundreds of such operations are realized each year. The major brake in the use of these technologies is the cost which is very expensive (about
$\$ 2000$ to $\$ 3000)$. In a study performed in another African country, it was found that one out of thirteen patients who were referred to ART centres was able to achieve her objective of motherhood [6].

At the legislative level, there was a lack of a law regulating ART until July 2001. At this period the NMEC gave some rules to conduct ART that take into account the Islamic viewpoint (Table 2). Recently, since August 2001, the law no 01-93, published in [7], strictly controls ART (Table 3). As the law was inspired by the HIC and the NMEC opinions on ART, there is no tension between the Islamic viewpoint and the secular one. Considering the difficulty to obtain gametes from a donor other than the partner, some couples go abroad, often to Europe, to benefit from the IVF technique or the artificial insemination (procreative tourism). Historical and geographical reasons made Europe the first destination for North African couples while the US centres 
are preferred by Egyptians and Saudi patients (Center for Surrogate Parenting and Egg Donation Inc, Encino, Calif, http://www.creatingfamilies.com). With regard to the use of embryos created by IVF, which are supernumerary, the law 01-93 (Table 3) as well as the NMEC in Tunisia (Table 2) have stated their opposition to all experimentation on the embryo which is regarded as a "potential person" (National Medical Ethics Committee, Opinion No. 1, Tunisia, 12 December 1996). In the French law, supernumerary embryos could be destroyed but could also be given to another couple who fulfils some conditions [8]. Swiss law also permits embryos donation and the child could have access to data related to the sperm donor [9].

\section{Genetically Modified Organisms}

Despite years of deployment of genetically modified crops (GMCs), there is no evidence of injury to people [10]. Public opinion on GMOs, one gene-technologybased application, varied from the condemnation or the distrust [11] to the support, the encouragement, and even the defense $[10,12,13]$. Finally, for others the harmlessness of GMOs is real and easy to demonstrate, while the escape of genes from GMCs to native species is considered inevitable $[14,15,16]$. Many observations and reasons suggested the importance of building public awareness and involving the public in the biotechnology development process. With regard to general opinion in Tunisia, no national surveys were done. The only study reporting public opinion about biotechnology was conducted under our supervision and has affected a population of 700 students (Ben Ameur R. Biologie et éthique: attitudes des étudiants du grand Tunis en matière de bioéthique; unpublished data). The results show that $61 \%$ of students were rather against the consumption of GM food. Interestingly, a clear refusal was recorded with girls (69\% versus $53 \%$ ) and literary sections, especially philosophical and sociological sections ( $84 \%$ of refusal attitudes); the mean refusal in scientific sections was about $48 \%$. Furthermore it was striking to note poor knowledge score related to GMOs even among scientific students (17\% of correct answers versus $2 \%$ in literary sections).

In Tunisia, only microorganisms and plants are involved in the gene technology. All experiences are enclosed in laboratories and research centres and there is no GMO culture in fields (ie, field-testing). With regard to animal feeding, corn and soya grains are imported without certification. As a very high percentage (about $80 \%$ ) of sailed corn in the world is transgenic, we think that corn bought in Tunisia is GM. Indeed, until now there was no procedure control and the country needs great quantity of corn for animal use. Moreover, there is no research on GM animals in Tunisia and officially there is no GM-based seed or seedling. Probably by application of the famous precautionary principle, researchers and other actors are waiting for a clear GMO policy.

A law project on GMO is in progress. The elaboration of such regulation is delicate and tricky because it must protect, at the same time, consumers, economy, environment, and scientific research. The main points of this law which have been discussed by different experts will be as follows.

(a) The law will concern GMOs importation, stocking, and transport.

(b) The law will not refuse GM products but will specify and make clear the conditions of importation.

(c) Some repressive measures will be taken to protect the consumer, to preserve the environment, and to control economic exchanges.

Since European countries constitute the main economic partners of Tunisia, one has to notice that the Tunisian law will take into account the European regulation.

In the same way, the law project will specify the composition and the functioning of the new National Committee of Biosafety and the conditions to produce GMOs.

What is the situation in African countries? The Organization of African Unity stressed the request of GMOs approval before its importation. Each GMO must be labelled such, and its producers would be responsible in the eyes of the law (zone libre d'OGM, les moratoires à travers le monde, http://www.infogm.org). In Egypt, GMCs were found to benefit Egyptian farmers by the reduction of pesticide application. GMCs authorized in this country are cotton, squash, potato, tomato, and corn [17]. In Kenya, a GM sweet potato resistant to virus has been introduced. Bt-maize has also been introduced and assayed against local stem borer species [18]. Kenya, South Africa, and Egypt are the first African countries that accepted GMOs testing in fields. Applications of biodigesters to generate biogas for lighting and heating are undertook in Ghana. In Zambia, government bans GM food aid offered by the US Agency for International Development via the World Food Program (WFP) [19].

In North Africa (ie, Maghreb), the people's reactions are likely to be similar to Tunisian ones because the three countries (Tunisia, Algeria, and Morocco) have the same religious considerations and cultural context. However, political will, specialized structures, and legislation are rather different.

The practice of the ART today in Morocco knows a fabulous fancy even in the absence of medical coverage which could help in the repayment of the medical expenses. It is interesting to note that the 15 centres of ART practising in Morocco are connected with private healthcare centres [20]. With about forty transplants, Morocco is far behind countries such as Tunisia and Kuwait. The legislation stays unsuitable and the organs donation is governed by the "dahir" of 1952, an obsolete text [21] With regard to Morocco's position to GMOs, and in application of the principle of precaution, a circular was established in August 1999 which forbids the introduction, on the national territory, of products and food preparations containing stemming products from GMO. The 
TABLE 4. Comparison of the regulatory situation and current usage for the three technologies OT, ART, and GMO. $(+++,++$, and + are strong, medium, and weak level, resp.)

\begin{tabular}{|c|c|c|c|c|}
\hline & Biotechnologies & OT & ART & GMO \\
\hline \multirow{4}{*}{ Achievements } & Education-research & ++ & ++ & ++ \\
\hline & Information & +++ & ++ & ++ \\
\hline & Legislation & +++ & ++ & + \\
\hline & Specialized structures & +++ & ++ & ++ \\
\hline \multirow{5}{*}{$\begin{array}{l}\text { Pressure } \\
\text { will or need }\end{array}$} & Political will & +++ & ++ & ++ \\
\hline & Users pressure and population need & ++ & +++ & \\
\hline & Scientists interest & ++ & + & ++ \\
\hline & Financial motivation of economic agents & & ++ & ++ \\
\hline & External pressure & & & +++ \\
\hline \multirow{2}{*}{ Remarks } & & $\begin{array}{l}\text { Political will was a } \\
\text { decisive factor }\end{array}$ & $\begin{array}{l}\text { Limited by religious } \\
\text { considerations }\end{array}$ & $\begin{array}{l}\text { Limited by safety } \\
\text { considerations }\end{array}$ \\
\hline & & $\begin{array}{l}\text { Response to a } \\
\text { real need }\end{array}$ & $\begin{array}{l}\text { Strong demand at } \\
\text { the population level }\end{array}$ & $\begin{array}{l}\text { Lack of expression of a real } \\
\text { need at the national level }\end{array}$ \\
\hline
\end{tabular}

only products allowed are those intended for the animal diet (eg, corn) and the import of GMOs seeds is forbidden. Finally, a project of law related to the control of the GMOs use and scattering, which aims to protect the human health, the animal health, and the environment of possible risks connected to the GMOs, is elaborated at the level of the Agricultural Department and submitted for approval [22].

In Algeria, the Order no 30 of October 15th, 2002, authorizes the taking and the transplantation of organs from corpses. In this country, GMOs import is banned since December 2000 and the sociocultural context is rather unfavourable to research development (http://www.infogm.org). Until today, there are no structures capable of detecting GMOs in the Maghreb countries. However, Algerian specialists think that the research in reproductive health is marginalized and very few efforts are granted in this direction [23]. In fact, ART were recently introduced in Algeria. The first step was realized in February 2003, by the birth of the first baby by ART in the private hospital of Boussouf in Constantine (http://www.1sante.com).

\section{CONCLUSION AND DISCUSSION}

The conditions offered in Tunisia to each of the 3 biotechnology examples presented above are different.

For OT, we can note that its development is ensured by wide information as a result of a legislation in its favour, the existence of specialized structures, and a clear political will as a decisive factor of success. An economical reason is also behind this will. In fact, developing OT at the national level allows the formation of skilled personnel and restricts expenditure. Furthermore, OT constitutes a response to a real need. Because the kidney diseases are frequent in the country, the first transplantation in Tunisia was kidney transplant.

In the case of the ART, the strong point in favour of its development is users pressure and population need. The ART is supported in Tunisia by a strong demand at the population level but it is limited by religious considerations (Table 4). In fact, the Islamic religion, by prohibiting the child adoption, pushes the couple who wants his "own" child to need ART.

With regard to GMOs, there is a lack of expression of a real need at the national economic level. Furthermore, this biotechnology is limited by safety considerations and the conditions for its development are rather difficult because decisions were taken at the political level and not at the individual one. Finally, legislation in favour of GMOs takes a long time.

Public debate on acceptance of biotechnology varied among countries and among technology's main applications. Generally, concerns are about the health, the food, and the environment. Biotechnology contribution to the progress of medicine through the last two decades did not arouse issues. There is an evident perceived potential benefit arising from biotechnology. On the other hand, in the agricultural field, GMOs give rise to quite a number of concerns. Those pros and cons have arguments and the planet has never been more divided over a question than on transgenic crops. This situation leads some organizations to participate in the debate and propose their viewpoints. The United Nations Development Programme (UNDP), for example, judges that development perspectives offered by GMOs require strong national policies with clear regulations to ensure that this technology does not destabilize development (Making new technologies work for human development. Annual report, UNDP, USA, July 2001). As for the International 
Service for National Agricultural Research (ISNAR), the government should not act hastily, but should rather approach the issue slowly and carefully to allow time to study the full implications of the new technology (ISNAR Annual report 1998, April 2000). Finally, the African Agency of Biotechnology (AAB) encourages the production, the distribution, and the commercialization of biotechnology products (AAB, http://www.aab.org.dz/francais.htm).

If we limit the analysis to the Tunisian country, it would be interesting to express the following recommendations.

(i) Importance of communication. We believed that communication is important to support biotechnology for GMOs. Our study has demonstrated a lack of information among public, even the educated people. Thus, a high percentage of Tunisian students never heard about transgenic food. It is worthwhile to notice that in Tunisia, although biotechnology is well accepted in the medical field, the actual conditions do not seem to be favourable to GMOs because of precisely, a lack of information. Scientists and the mass media would find the appropriate way to communicate with the public. They should inform the nonspecialists on stakes and help the society to take advantage of the biotechnology advances [24]. Political and financial measures should be taken to encourage the dissemination of scientific and technological information. Concretely, scientific and medical associations, the "City of Sciences," and the journalists could play this role. The role of these actors is to report the biotechnology facts as well as to present the issues and the expected benefits. Thus, the public will be able to judge and to separate between what is factual from what is speculative. What we need is the establishment of a balanced view of biotechnology: its risks and its beneficial potential [25].

(ii) Establishing and enforcing rules and regulations on biotechnology. Our analysis has shown that in Tunisia, biotechnology supported by law and regulations (ie, ART and OT) is more accepted than that waiting for a legislation (ie, GMOs). Moreover, legislation reassures the public and the scientists and protects the country's economical interests.

(iii) Ethical considerations. It is true that since 1992, the Tunisian country has been dotted with an ethics committee but this committee is active rather in medical fields and has never published opinions related to plant biotechnology (ie, GMOs). This problem is important in view of the issues related to GMCs. We believe that for a successful policy framework, it is necessary to first set up a local national biotechnology committee of experts, government, and private sector representatives to overview biotechnology activities.

In conclusion, when safety exceeds risks, intrinsic considerations are over external pressures and when the political will and the popular demand go hand in hand, then the conditions are favourable to the development of a given technology. In any case, more information, training, research, regulation, coordination, democracy, ethics, and more wisdom can be recommended.

\section{REFERENCES}

[1] Modalités et procédures de prélèvements et de greffe d'organes. Official Journal of Tunisia Republic. 29 March 1991;(22):467.

[2] Lois. Official Journal of Tunisia Republic. 5 March 1999;(19):34.

[3] Belkhodja MH. Les greffes d'organes. In: International Meeting on Bioethics; October 1997; Tunisia.

[4] El-Shahat YIM. Islamic viewpoint of organ transplantation. Transplant Proc. 1999;31(8):3271-3274.

[5] Hamza B. Greffe d'organes et éthique médicale. In: 9th medical siminar IBN EL JAZZAR; April 23-24, 1999; Tunisia.

[6] Serour GI, Aboulghar MA, Mansour RT. In vitro fertilization and embryo transfer in Egypt. International Journal of Gynecology and Obstetrics. 1991;36:49-53.

[7] Lois no 93 du 7 Août 2001 concernant la procréation médicalement assistée. Official Journal of Tunisia Republic. 7 August 2001;(63):171.

[8] Harichaux M. Aspects juridiques de l'assistance médicale à la procréation. In: Ières Journées Pédagogiques d'Éthique Médicale d'Amiens; September 1997; Amiens, France.

[9] Georges D. L'insémination artificielle avec donneur est-elle en danger? Médecine Science. 1985;(1):154157.

[10] Murdock L. Cowpea (Vigna unguiculata) and crop genetic transformation in general. ABiotec. June 2002;(7):1-5.

[11] El Baksami N. Position de la religion et de la philosophie face au génie génétique. In: Le Génie Génétique et l'Éthique. Number 174 in Alem al Maarifa, Kuwait: National Council of Culture, Arts, and Literature Eds; 1993:201.

[12] Nossal G. L'histoire et l'opposition au génie génétique. In: Génie Génétique, Réalités et Promesses, France: Masson ed; 1988:164.

[13] Ammann K. Les OGM entre mensonges et hystérie. La Recherche. 1999;325:104-107.

[14] Thuriaux P. Plantes transgéniques et proscrastination, l'analyse scientifique peut-elle rassurer le grand public? La Recherche. 1998;(313):8.

[15] Cockburn A. Assuring the safety of genetically modified (GM) foods: the importance of an holistic, integrative approach. Journal of Biotechnology. 2002;98(1):79-106.

[16] Mosely BE. Safety assessment and public concern for genetically modified food products: the European view. Toxicologic Pathology 2002;30(1):129-131.

[17] Agricultural Genetic Engineering Research Institute. Genetically modified crops to benefit Egyptian farmers. ABiotec. June 2002;(7):5.

[18] Odhiambo B, Gichuki S. Status of GMO research in Kenya. ABiotec. June 2002;(7):7.

[19] Knight W. Zambia bans GM food aid. New Scientist Online Newsletter. October 2002. 
[20] Cherkaoui A. Lever les tabous et les préjugés sur la stérilité des couples au Maroc. Libération. 12 December 2003.

[21] El Azizi A. La greffe est déclarée. Maroc Hebdo International. January 1999;(355):23.

[22] Chouibani M. Situation des OGM au Maroc. In: Workshop International: Apport des Biotechnologies en Production Intégrée; October 2003; Marrakech.

[23] Kellil M, Bounecer H, Boussouf N, et al. "Santé reproductive." In: Séminaire Atelier sur la Santé Reproductive à l'Institut Technologique de Santé Publique de Constantine; March 2003; Algiers.

[24] Gareis H. Génie génétique et responsabilité industrielle. Biofutur. 1983;(18):6-7.

[25] Rode BM. Public Awareness and Participation in Science Policy Making. In: United Nations Commission on Science and Technology for Development, Panel meeting on Biotechnology; November 2000; Tunisia.

* Corresponding author.

E-mail: fateb@planet.tn

Fax: +216 71 885480; Tel: +21671872600 

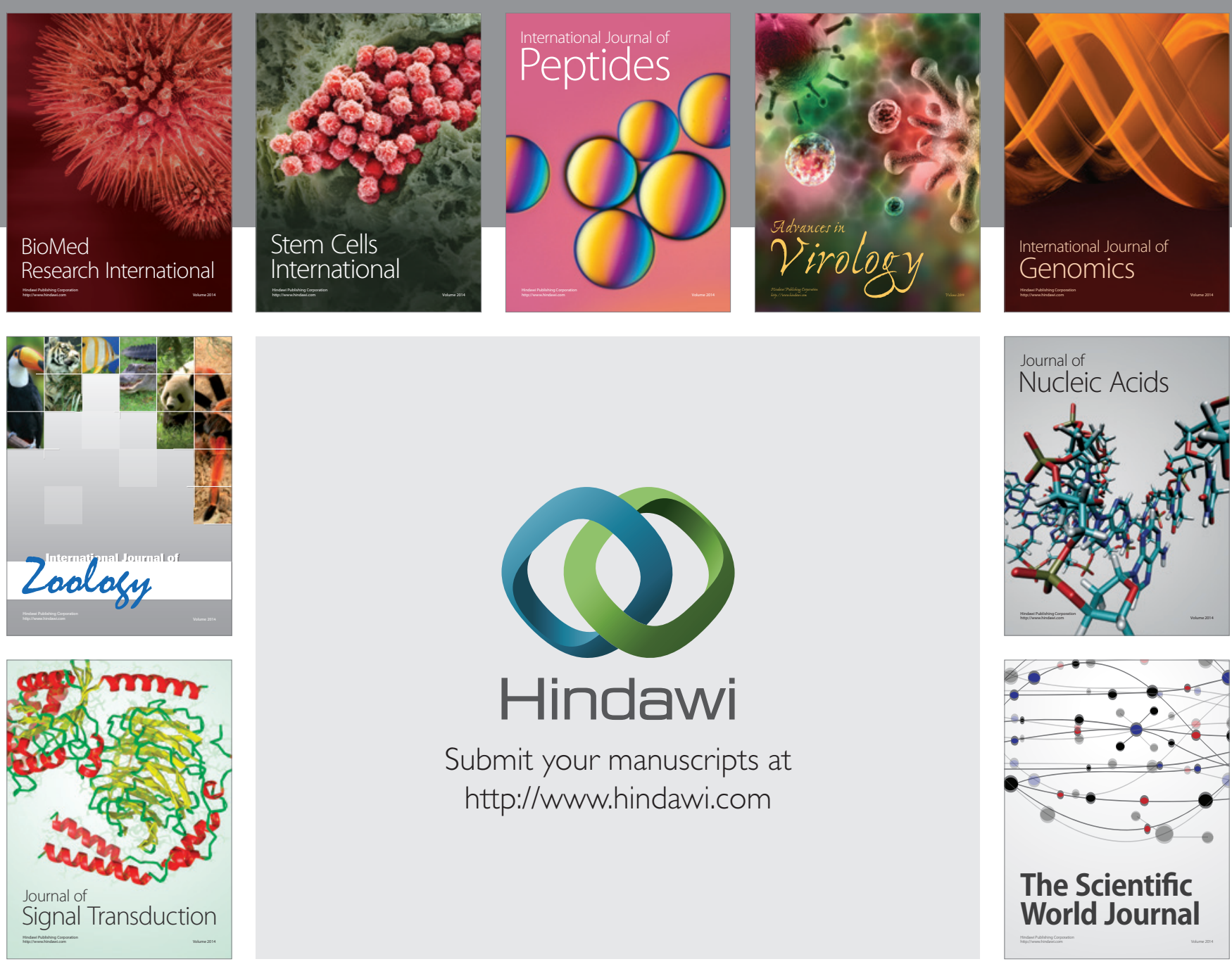

Submit your manuscripts at

http://www.hindawi.com
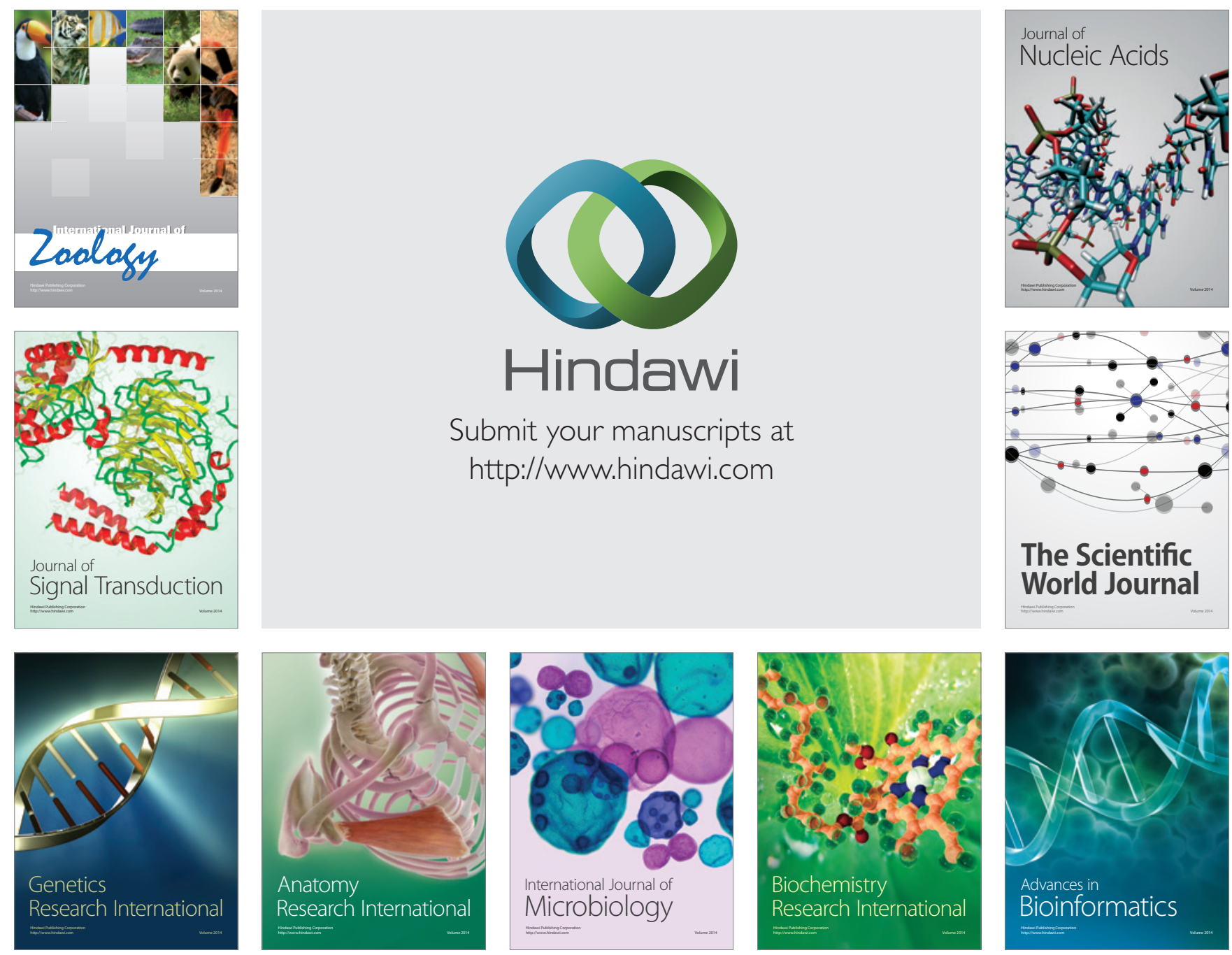

The Scientific World Journal
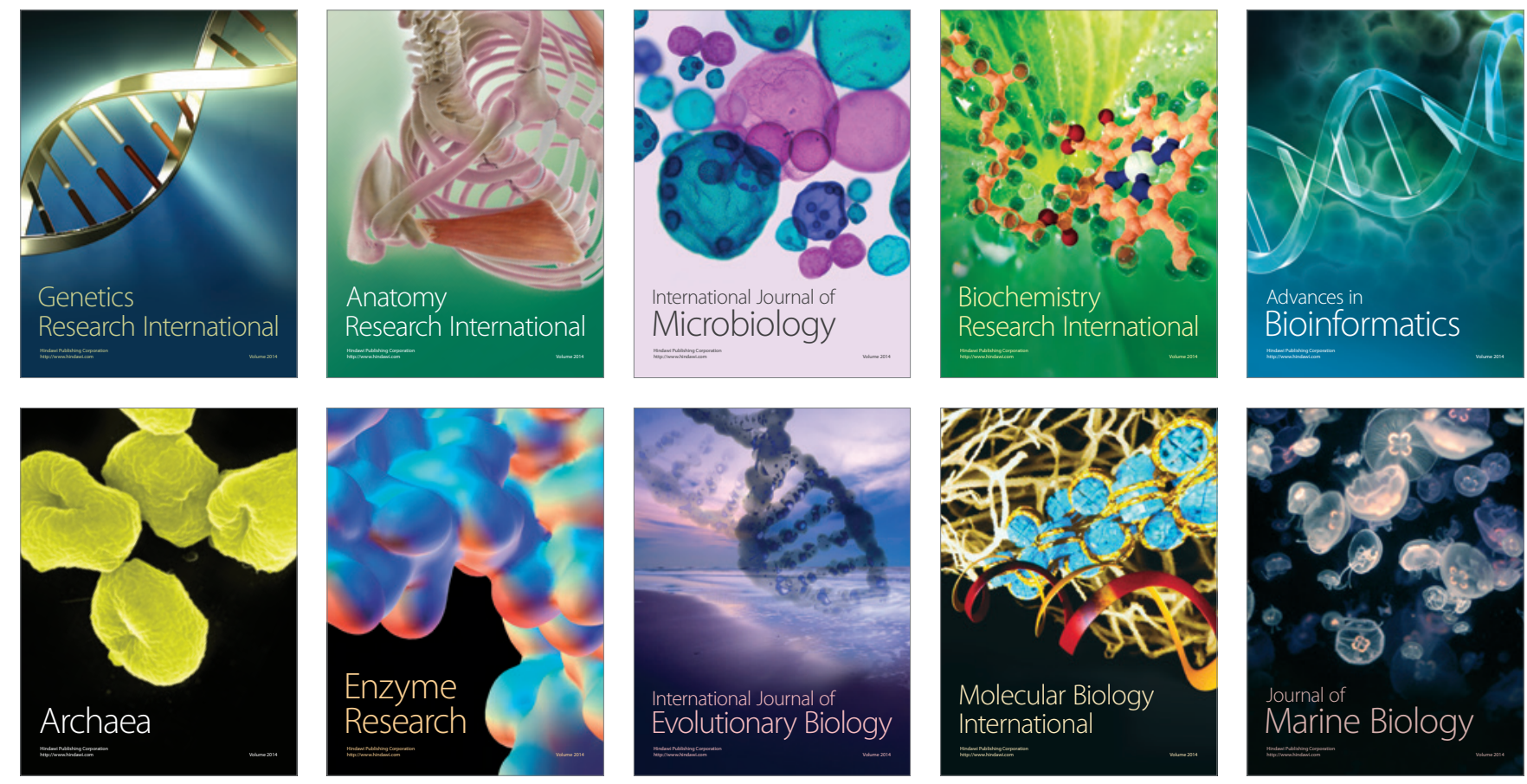